\title{
The Use Of Payment Cards In Kazakhstan: Analysis And Forecast
}

\author{
Anna A. Kredina ${ }^{*}$, Olga V. Koshkina ${ }^{1}$, László Vasa ${ }^{2}$ \\ ${ }^{1}$ University of International Business, Abay Avenue 8a, 050010, Almaty, Kazakhstan \\ ${ }^{2}$ Széchenyi István University, Györ, Hungary
}

\begin{abstract}
The aim of the study is to analyze and forecast the use of payment cards for making non-cash payments through national payment systems in Kazakhstan. Based on this goal, a hypothesis was put forward that in Kazakhstan, there is a relationship between the number of payment cards and the volume of non-cash payments. This hypothesis was confirmed because of the study. The information base of the study was the data on payment cards, which were taken from the Statistical Bulletin of the National Bank of the Republic of Kazakhstan. Hypothesis testing was carried out using correlation analysis for three periods: 2009, 2016, 2020. The method of finding Pearson's correlation in the SPSS program was used. The results showed a downward change in the relationship between the selected indicators and the amount of funds transferred over time. Also, in this study, a forecast was made for 2021-2023 for the indicators under consideration. To make a forecast for the indicators under consideration, a graphical method (polynomial trend line) was used. The resulting forecast shows the growth of cardholders and, consequently, the spread of the number of payment cards among the population in 2021-2023. The practical significance of this study is that the proposed methodology can help predict the dynamics of payment cards in any country in the world. Recommendations are also given for further improving the financial system, since increasing the transparency of monetary circulation in small-and-medium sized businesses will lead to a positive result in the implementation of the program for universal declaration of income in 2025.
\end{abstract}

Keywords: payment cards, cashless payments, Kazakhstan, forecast

For citation: Kredina,A.A., Koshkina, O.V. \& Vasa, L. (2021). The Use Of Payment Cards In Kazakhstan: Analysis And Forecast. Economics: the Strategy and Practice, 16(3), 106-116, https://doi.org/10.51176/1997-9967-2021-3$\underline{106-116}$

* Corresponding author: Anna A. Kredina - PhD student of UIB, Department of Finance and Accounting University of International Business, 050010, Almaty, Ave. Abay8a, Kazakhstan, +87012862176 , e-mail: anna. kredina@uib.kz

Conflict of interests: the authors declare that there is no conflict of interest

Financial support: The study was not sponsored (own resources).

The article received: 13.05 .2021

The article approved for publication: 18.05 .2021

Date of publication: 30.09 .2021 


\title{
Казақстанда төлем карталарын қолдану: талдау және болжам
}

\author{
Кредина А.А. ${ }^{*}$, Кошкина О.В. ${ }^{1}$, Васа Ласзло² \\ ${ }^{1}$ Халықаральқ Бизнес Университеті, Абай д., 8А, 050010, Алматы, Қазақстан \\ ${ }^{2}$ Сечени Иитван Университеті, Дьер, Венгрия
}

\section{Түйін}

Қазақстанда 2016 жылдан бастап қаржы жүйесінің трансформациясы ұлттық төлем жүйелері арқылы ақша транзакцияларының өсуіне алып келді. Алғашқы төлем карталары банкоматтардан қолма-қол ақша алу үшін пайдаланылса да (негізінен бұл үшін жалақы карталары пайдаланылды), қазір ең өзекті процесскарточкалық аударымдарды жүзеге асыру. Зерттеудің ақпараттық базасы Қазақстан Республикасы Ұлттық Банкінің статистикалық бюллетенінен алынған төлем карталары бойынша деректер болды. Қойылған мақсатқа сүйене отырып, Қазақстанда төлем карталарының саны мен қолма-қол ақшасыз есеп айырысу көлемі арасында өзара байланыс бар деген болжам жасалды. Бұл гипотеза зерттеу нәтижесінде расталды. Зерттеудің ақпараттық базасы ретінде төлем карталары бойынша деректер Қазақстан Республикасы Ұлттық Банкінің статистикалық бюллетенінен алынды. Гипотезаларды тексеру корреляциялық талдау арқылы үш кезеңде жүргізілді: 2009, 2016, 2020 жылдар. The method of finding Pearson's correlation in the SPSS program was used. Нәтижелер таңдалған индикаторлар мен уақыт өте келе аударылған ақша қаражатының саны арасындағы өзара байланыстың азаю жағына қарай өзгергенін көрсетті. Сондай-ақ осы зерттеуде қарастырылған индикаторлар бойынша 2021-2023 жылдарға арналған болжам жүргізілді. Қаралатын индикаторлар бойынша болжам жасау үшін графикалық әдіс (трендтің көпмүшелік сызығы) қолданылды. Алынған болжам карта ұстаушылардың өсуін және нәтижесінде 2021-2023 жылдары төлем карталары санының халық арасында таралуын көрсетеді. Бұл зерттеудің практикалық маңыздылығы-ұсынылған әдіс әлемнің кез-келген еліндегі төлем карталарының динамикасын болжауға көмектеседі. Сондай-ақ, қаржы жүйесін одан әрі жетілдіру үшін ұсынымдар берілді, өйткені шағын және орта бизнестегі ақша айналымының ашықтығын арттыру 2025 жылы кірістерді жалпыға бірдей декларациялау бағдарламасын жүзеге асыру кезінде оң нәтижеге әкеледі.

Tүйін сөздер: төлем карталары, қолма-қол ақшасыз төлемдер, Қазақстан, болжам

Дәйексөз алу үшін: Кредина А.А., Кошкина О.В., Васа Ласзло (2021). Қазақстанда төлем карталарын қолдану: талдау және болжам . Экономика: стратегия және практика, 16(3), 106-116 , https://doi.org/10.51176/1997-99672021-3-106-116

* Хат-хабаршы авторы: Кредина Анна Александровна - Халықаралық Бизнес Университеті, 050010, Алматы, Абай даңғылы, 8А, Қазақстан, +87012862176, e-mail: anna.kredina@uib.kz

Мүдделер қақтығысы: авторлар мүдделер қақтығысының жоқтығын мәлімдейді.

Қаржыландыру. Зерттеу демеушілік қолдау көрсеткен жоқ (меншікті ресурстар).

Мақала редакцияға түсті: 13.05 .2021

Жариялау туралы шешім қабылданды: 18.05.2021

Жарияланды: 30.09 .2021 


\title{
Использование платежных карт в Казахстане: анализ и прогноз
}

\author{
Кредина А.А. ${ }^{*}$, Кошкина О.В. ${ }^{1}$, Васа Ласзло ${ }^{2}$ \\ ${ }^{1}$ Университет международного бизнеса, пр. Абая 8а, 050010, Алматы, Казахстан \\ ${ }^{2}$ Сечени Иитван Университеті, Дьер, Венгрия
}

\begin{abstract}
Аннотация
Целью исследования является анализ и прогнозирование использования платежных карт для осуществления безналичных платежей через национальные платежные системы в Казахстане. Исходя из поставленной цели были выдвинута гипотеза о том, что в Казахстане имеется взаимосвязь между количеством платежных карт и объемом безналичных расчетов. Данная гипотеза в результате проведенного исследования подтвердилась. Информационной базой исследования послужили данные по платежным картам, которые были взяты из Статистического Бюллетеня Национального Банка Республики Казахстан. Проверка поставленных гипотез осуществлялась с помощью корреляционного анализа за три периода: 2009, 2016, 2020 годы. Был использован метод нахождения корреляции Пирсона в программе SPSS. Результаты показали изменение взаимосвязей в сторону уменьшения между выбранными индикаторами и количеством переведенных денежных средств с течением времени. Также в данном исследовании был проведен прогно3 на 2021-2023 годы по рассматриваемым индикаторам. Для составления прогноза по рассматриваемым индикаторам применялся графический метод (полиномиальная линия тренда). Полученный прогноз показывает рост держателей карт и как следствие распространение количества платежных карт среди населения в 2021-2023 годах. Практическая значимость данного исследования состоит в том, что предложенная методика может помочь спрогнозировать динамику по платежным картам в любой стране мира. Также даны рекомендации для дальнейшего совершенствования финансовой системы, так как повышение прозрачности денежного оборота в малом и среднем бизнесе приведет к положительному результату при осуществлении программы по всеобщему декларированию доходов в 2025 году.
\end{abstract}

Ключевые слова: платежные карты, безналичные расчеты, Казахстан, прогноз.

Для цитирования: Кредина А.А., Кошкина О.В., Васа Ласзло (2021). Использование платежных карт в Казахстане: анализ и прогноз. Экономика: стратегия и практика, 16(3), 106-116, https://doi.org/10.51176/19979967-2021-3-106-116

* Корреспондирующий автор: Кредина Анна Александровна - Университет международного бизнеса, 050010, Алматы, проспект Абая 8a, Казахстан, +87012862176, e-mail: anna.kredina@uib.kz

Конфликт интересов: авторы заявляют об отсутствии конфликта интересов.

Финансирование. Исследование не имело спонсорской поддержки (собственные ресурсы).

Статья поступила в редакцию: 13.05 .2021

Принято решение о публикации: 18.05 .2021

Опубликовано: 30.09 .2021 


\section{Introduction}

The appearance of payment cards has simplified the life of the population of the countries of Central Asia. As a result of the transformation of the financial system, since 2016, there has been a tendency towards an increase in monetary transactions through national payment systems in Kazakhstan. There are many articles on the interaction of ATMs with payment cards. The first payment cards were used to withdraw cash from ATMs [1]. Mainly salary cards were used for this. There is also a global trend - an increase in the population using cards (debit, credit). payment cards scientists have learned to predict the economic growth of entire countries [2].

"Non-cash payments are made only with a bank card" - this perspective has existed for many years. In the study, we decided to test the relevance of this theory. The study aims to analyze and forecast the use of payment cards for making non-cash payments through national payment systems in Kazakhstan. Based on this goal, the following hypotheses can be put forward (zero and alternative):

$\mathrm{HO}$ - null hypothesis - there is no relationship between payment cards and the volume of cashless payments in Kazakhstan.

$\mathrm{H} 1$ - an alternative hypothesis - there is a relationship between payment cards and the volume of cashless payments in Kazakhstan.

The economic interpretation of the rationale for this hypothesis is that an increase in the number of payment cards in the future will likely lead to an increase in non-cash payments.

\section{Literature review}

The replacement of cash proceeded in stages: money - checks - credit cards - debit cards. The first payment cards were used to withdraw cash from ATMs. At the same time, there was no need to pay a withdrawal fee if the ATM is serviced by the same bank that issued the plastic card. Humphrey, in his study, developed an econometric model that predicted a decrease in cash in Poland [3]. Now in Kazakhstan, the marginality of the financial system is also occurring: cash payments are gradually being replaced by non-cash payments. This is facilitated by the state program "Digital Kazakhstan" - access to broadband Internet leads to the proliferation of ATMs and online banking. Banks are also active in installing ATMs away from large settlements.

In Europe (Hungary, Poland, Germany) and East Asia (China, Singapore, Japan, etc.), the number of transfers began to actively prevail over the number of withdrawals from ATMs earlier (from the beginning of 2016) than in the CIS countries (Ukraine, Kazakhstan). However, in most countries, the proliferation of payment cards occurred as a consequence of the COVID-19 pandemic [4]. The main factor in this is the development of online banking and the distribution of debit cards [5].

The transformation of financial technologies has led to the emergence of such ATMs that issue a personalized plastic card (in Kazakhstan, the development of Kaspi Bank). Moreover, the next stage is the emergence of web ATMs, in which users will be able to carry out transactions directly on the screen without using bank cards. Of course, such systems are rigorously tested by banks for accurate user identification and security before implementation [6].

Scientist Salsabila examined the experience of spreading electronic money in Indonesia. According to his forecasts, electronic money will soon begin to prevail over card payments. The distribution of plastic cards is also influenced by such factors as age and education [7]. According to the National Bank of Poland, people with higher education are more often characteristic to own payment cards and use electronic money in circulation [8].

At the same time, the effect of connecting settlements to the Internet does not lead to an increase in payment cards. This is due to the financial literacy of the population, the proliferation of bank branches and other regional factors. So, for example, in Russia, with the spread of the Internet, by 2018 only in Moscow and the Moscow Region, the increase in transactions for paying for services and goods by payment cards reached $22 \%$. In other regions, this indicator was significantly lower [9]. In Kazakhstan, in order to maintain the positive effect of non-cash money circulation, an increase in financial literacy among the population is being carried out.

Forecasting based on data on payment cards is used by different scientists. Some deduce econometric models based on time series and predict the excess of wire transfer transactions. Moreover, this forecast, in fact, has come true in recent years [10]. Some make such forecasts for several countries (since the trend towards noncash payments in different countries has a different speed). In doing so, the banking system as a whole wins, as producing cash is more expensive than conducting cashless transactions [11]. Kazakhstan embarked on the path of such a transformation in 2020.

Similarly, researchers Aprigliano, V., Ardizzi, G., \& Monteforte, L. prove the positive effect of the use of plastic cards: there is a relationship between the level of economic growth of the country and card payments [12]. In another study, using data on transactions and applying the principle of LASSO 
(least absolute shrinkage and selection operator), they derive a model that shows that an increase in non-cash transfers increases in GDP. Thus, we will try to predict the level of wire transfers in Kazakhstan using the methodology described below [13].

\section{Metodology}

The theoretical and methodological basis of the study was the works of foreign scientists. Secondary data on payment cards, payment card holders and also on non-cash payments passing through the national payment systems Interbank System of Money Transfer (ISMT) and Interbank Clearing System (ICS) for the period from 2004 to 2020 ("Statistical Bulletin ...", 2004 -2020) were taken from the website of the National Bank of the Republic of Kazakhstan. Research methods used to write this study: economic-statistical analysis and synthesis, correlation analysis, graphical method (polynomial trend line) [14].

In this study, the dependent variable is the number of payments (thousand transactions). There are several independent variables, namely: the volume of payments (billion tenge), the number of cardholders (thousand), the total number of cards in circulation (thousand), the total number of used payment cards (thousand).

For the convenience of calculations, we will encode the data (the results are in Table 1).

Table 1 - Variables used in the study

\begin{tabular}{|l|l|}
\hline Description & Abbreviation \\
\hline $\begin{array}{l}\text { Number of payments, thous. } \\
\text { transactions }\end{array}$ & Numb_P \\
\hline $\begin{array}{l}\text { The volume of payments, billion } \\
\text { tenge }\end{array}$ & Vol_P \\
\hline Number of card holders, thous. & Card_Hold \\
\hline $\begin{array}{l}\text { Total number of cards in circulation, } \\
\text { thous }\end{array}$ & Numb_Card \\
\hline $\begin{array}{l}\text { Total of used payment cards, thous. } \\
\text { units }\end{array}$ & Used_Card \\
\hline
\end{tabular}

Source: Compiled by the authors

The essence of correlation analysis is to calculate the coefficients of the relationship between variables. These coefficients can be calculated using statistical programs.In general, in various scientific studies it is customary to use the formula for calculating the Pearson correlation coefficient, which is calculated by the formula below (1):

$$
r_{x y}=\frac{\Sigma\left(x_{i}-\bar{x}\right) *\left(y_{i}-\bar{y}\right)}{\sqrt{\Sigma\left(x_{i}-\bar{x}\right)^{2} *\left(y_{i}-\bar{y}\right)^{2}}}
$$

where - the values of the variable $\mathrm{X}$;

- the values of the variable Y;

- arithmetic mean for variable X;

- arithmetic mean for variable $\mathrm{Y}$.

The multiple regression equation can be represented as:

$$
\mathrm{Y}=\mathrm{f} \cdot(\beta, \mathrm{X})+\varepsilon,(2)
$$

where $\mathrm{X}=\mathrm{X} *(\mathrm{X} 1, \mathrm{X} 2, \ldots, \mathrm{Xm})$ - vector of independent (explanatory) variables;

$\beta$ - vector of parameters (to be determined);

$\varepsilon$ - random error (deviation);

$\mathrm{Y}$ - dependent (explained) variable.

To achieve this goal, we will perform the following steps:

Step 1: collecting and analyzing data on the number of transactions for 2004-2020;

Step 2: collection and analysis of data on the number of payment cards, payment card holders;

Step 3: testing data for normal distribution;

Step 4: finding the Pearson correlation coefficients;

Step 5: making a forecast.

A trend line is used to visually illustrate trends in indicators. The element of technical analysis is a geometric image of the average values of the analyzed indicator. In this study, a graphical method (polynomial trend line) will be used to make a forecast for the indicators under consideration. Every 5 years it is possible to forecast data for 1 year ahead, in this study the period under consideration is 17 years, so the forecast can cover 3 years (2021-2023).

\section{Analysis}

According to the report of the analytical service Cable.co.uk (the price of fixed-line broadband in 211 countries) for 2020, Kazakhstan ranks 7 th in the world in terms of the cheap cost of the Internet [15]. The average cost of broadband access (per megabit per month) is USD 0.65 . The average cost of a package per month 4100 tenge (9.46 US dollars). In terms of the average cost of mobile Internet for 2020, Kazakhstan ranks 20th in the world (0.59 USD). Cheap access to the Internet network is determined by the reduction in the costs of its implementation and maintenance. As a consequence, this spread of the Internet leads to the use of smartphones and payment applications to which payment bank cards are linked.

Figure 1 shows the dynamics in the number and volume of monetary transactions through national payment systems from 2004 to 2020 . 


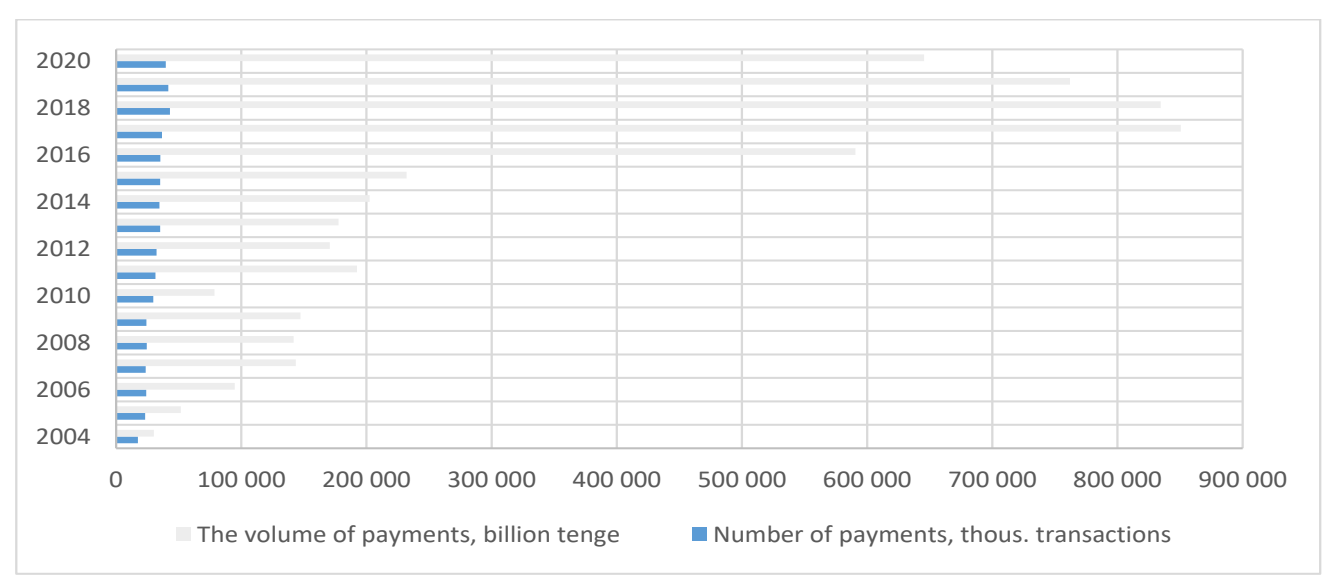

Figure 1 - The number and volume of non-cash payments in Kazakhstan

Source: National Bank of the Republic of Kazakhstan.

It can be seen that in recent years there has been a decrease in the number and volume of noncash transfers in Kazakhstan. This trend is primarily caused by the impact of the 2020 global crisis caused by the COVID -19 pandemic. It is thanks to the pandemic that the world has shifted towards the prevalence of remittances over cash withdrawals. But the impact of the pandemic on the business sector is still ongoing. The negative point is that the lack of stability in the introduction of quarantine and lockdown leads to inconsistent earnings, the business suffers losses. A positive moment from the increase in the number of non-cash payments is a way out of the shadow economy of small and medium-sized businesses (in Kazakhstan, by 2025, universal income declaration will be introduced). Table 2 shows the change in the number of plastic cards and payment card holders in Kazakhstan from 2004 to 2020.

Table 2 - Dynamics of payment cards and their holders in Kazakhstan

\begin{tabular}{|c|c|c|c|}
\hline Year & $\begin{array}{l}\text { Number of card holders, } \\
\text { thous. }\end{array}$ & $\begin{array}{l}\text { Total number of cards in } \\
\text { circulation, thous. }\end{array}$ & $\begin{array}{l}\text { Total number of used payment } \\
\text { cards, thous. units }\end{array}$ \\
\hline 2004 & 2274 & 2359 & 1438 \\
\hline 2005 & 3075 & 3215 & 1931 \\
\hline 2006 & 3933 & 4101 & 2421 \\
\hline 2007 & 5334 & 5616 & 2971 \\
\hline 2008 & 6643 & 7173 & 3219 \\
\hline 2009 & 7136 & 7615 & 3694 \\
\hline Growth, \% & 314 & 323 & 257 \\
\hline 2010 & 7817 & 8392 & 4272 \\
\hline 2011 & 8855 & 9569 & 4519 \\
\hline 2012 & 11081 & 12140 & 6346 \\
\hline 2013 & 14378 & 16544 & 6892 \\
\hline 2014 & 15170 & 17276 & 7219 \\
\hline 2015 & 14309 & 17162 & 8481 \\
\hline Growth, \% & 183 & 205 & 199 \\
\hline 2016 & 14209 & 15703 & 8420 \\
\hline 2017 & 17012 & 19411 & 9882 \\
\hline 2018 & 18980 & 23390 & 11406 \\
\hline 2019 & 29793 & 32048 & 18176 \\
\hline 2020 & 39208 & 47966 & 26779 \\
\hline Growth, \% & 276 & 305 & 318 \\
\hline $\begin{array}{l}\text { Growth for the whole period } \\
(2004-2020), \%\end{array}$ & 1724 & 2033 & 1862 \\
\hline
\end{tabular}

Source: Compiled by the authors. 
The data in the table was divided into three periods 2004-2009, 2010-2015, 2016-2020. The analysis shows that the most active period of increase in the number of payment card holders is $2004-2009-314 \%$, a slowdown is observed in 2010-2015. In the third period, the increase in cardholders (276\%) was associated with 2020 39,208 thousand users.

The total number of payment cards (this includes local and international plastic cards) increased most actively in 2004-2009 (323\%), although the largest number is observed in 2020 47966 thousand. Compared with the population of
Kazakhstan as of December 31, 2020 (18 953799 people), it turns out that for every 10 people there are 25 plastic cards. Used plastic cards repeat the dynamics of issued payment cards.

The year 2020 should also be highlighted, since the highest ones in terms of the number of cardholders, the number of issued and used cards were achieved exactly this year (39208, 47966 and 26779 , respectively). The table below provides a test for the normal distribution of data (KolmogorovSmirnov test), which will help determine whether the correct method for calculating the correlation coefficients has been chosen.

Table 3 - One-Sample Kolmogorov-Smirnov Test

\begin{tabular}{|c|c|c|c|c|c|c|c|c|}
\hline \multirow{2}{*}{\multicolumn{3}{|c|}{$\mathrm{N}$}} & V1 & V2 & V3 & V4 & V5 & V6 \\
\hline & & & 17 & 17 & 17 & 17 & 17 & 17 \\
\hline \multirow{2}{*}{$\begin{array}{l}\text { Normal } \\
\text { Parameters }\end{array}$} & \multicolumn{2}{|l|}{ Mean } & 31276,24 & 12865,53 & 14687,06 & 7533,29 & 473284,24 & 10120114,76 \\
\hline & \multicolumn{2}{|c|}{ Std. Deviation } & 7370,8 & 9725,22 & 11675,24 & 6501,67 & 791864,93 & 13358762,86 \\
\hline \multirow{3}{*}{$\begin{array}{l}\text { Most } \\
\text { Extreme } \\
\text { Differences }\end{array}$} & \multicolumn{2}{|c|}{ Absolute } & ,176 &, 171 & ,177 & ,207 &, 336 & ,261 \\
\hline & \multicolumn{2}{|l|}{ Positive } &, 176 &, 171 &, 177 & 207 &, 336 & 261 \\
\hline & \multicolumn{2}{|l|}{ Negative } &,- 148 &,- 138 &,- 146 &,- 174 &,- 291 &,- 237 \\
\hline \multicolumn{3}{|l|}{ Test Statistic } &, 176 &, 171 &, 177 & ,207 & ,336 & 261 \\
\hline \multicolumn{3}{|c|}{ Asymp. Sig. (2-tailed) ${ }^{c}$} & 169 & 200 &, 163 &, 052 & $<, 001$ &, 003 \\
\hline \multirow{3}{*}{$\begin{array}{l}\text { Monte } \\
\text { Carlo Sig. } \\
\text { (2-tailed) }^{\mathrm{d}}\end{array}$} & \multicolumn{2}{|l|}{ Sig. } & 173 & 203 &, 168 & 051 &, 000 &, 003 \\
\hline & \multirow{2}{*}{$\begin{array}{l}99 \% \\
\text { Confidence } \\
\text { Interval }\end{array}$} & $\begin{array}{l}\text { Lower } \\
\text { Bound }\end{array}$ &, 163 & , 193 &, 158 &, 046 & 000 &, 001 \\
\hline & & $\begin{array}{l}\text { Upper } \\
\text { Bound }\end{array}$ & , 183 & ,214 & ,177 & 057 & 000 & ,004 \\
\hline \multicolumn{9}{|c|}{ a. Test distribution is Normal. } \\
\hline \multicolumn{9}{|c|}{ b. Calculated from data. } \\
\hline \multicolumn{9}{|c|}{ c. Lilliefors Significance Correction. } \\
\hline \multicolumn{9}{|c|}{ d. Lilliefors' method based on 10000 Monte Carlo samples with starting seed 92208573.} \\
\hline
\end{tabular}

Source: Compiled by the authors.

Based on the results of the table, we can conclude that the data have a normal distribution. This means that the Pearson method will be used to determine the relationship between the selected indicators.

\section{Results and discussion}

The correlation coefficients were found and the results were compared in SPSS program. The coefficients were found separately for each year. Below is table 3, which compares the results of the correlation analysis for 3 periods: 2009, 2015, 2020. The results were entered into the correlation matrix.

This matrix shows that all indicators correlate not only with the number of payments, but also with each other.
The trend for 2004-2009. According to the results of the study, in this period, the largest positive relationship exists between holders of payment cards and between the volume of payments (, $996 * *)$. Interestingly, this strong relationship persists throughout the period under review. This can be explained by the fact that the first non-cash transactions were conducted by the owners once a month to withdraw cash from ATMs. And at present, without a plastic card, there is no possibility of using mobile applications to pay for goods or services.

Trend for 2010-2015. The largest correlation is observed between holders of payment cards and between the number of plastic cards (, 996 **). Also, the higher the number of payments, the higher the volume of monetary transactions (, 973 **). During this period, the banks' competitors are actively developing: non-bank payment systems. 
Table 4 - Obtained correlation coefficients (Sig. (2-tailed))

\begin{tabular}{|c|c|c|c|c|c|}
\hline Indicator & Years & Numb_P & Vol_P & Card_Hold & Numb_Card \\
\hline \multirow{6}{*}{ Numb_P } & \multirow{2}{*}{ 2004-2009 } & \multirow[t]{2}{*}{1} & 0,716 & 0,694 & 0,757 \\
\hline & & & $(0,110)$ & $(0,126)$ & $(0,082)$ \\
\hline & \multirow{2}{*}{$2010-2015$} & 1 &, $973^{* *}$ &, $979^{* *}$ & ,916* \\
\hline & & & 0,001 & 0,001 & 0,010 \\
\hline & \multirow{2}{*}{$2016-2020$} & 1 & 0,437 & 0,435 & 0,395 \\
\hline & & & $(0,462)$ & $(0,464)$ & $(0,510)$ \\
\hline \multirow{6}{*}{ Vol_P } & \multirow{2}{*}{ 2004-2009 } & 0,716 & 1 & ,996** & ,979** \\
\hline & & $(0,110)$ & & $(0,000)$ & $(0,000)$ \\
\hline & \multirow{2}{*}{$2010-2015$} &, $973^{* *}$ & 1 & ,996** & ,916* \\
\hline & & $(0,001)$ & & $(0,000)$ & $(0,010)$ \\
\hline & \multirow{2}{*}{ 2016-2020 } & 0,437 & 1 &, $990^{* *}$ &, $996^{* *}$ \\
\hline & & $(0,462)$ & & $(0,001)$ & $(0,000)$ \\
\hline \multirow{6}{*}{ Card_Hold } & \multirow{2}{*}{ 2004-2009 } & 0,694 &, $996^{* *}$ & 1 & ,983** \\
\hline & & $(0,126)$ & $(0,000)$ & & $(0,000)$ \\
\hline & \multirow{2}{*}{$2010-2015$} &, $979^{* *}$ & ,996** & 1 &, $937^{* *}$ \\
\hline & & $(0,001)$ & $(0,000)$ & & $(0,006)$ \\
\hline & \multirow{2}{*}{$2016-2020$} & 0,435 & ,990** & 1 & ,996 \\
\hline & & $(0,464)$ & $(0,001)$ & & $(0,000)$ \\
\hline \multirow{6}{*}{ Numb_Card } & & 0,757 &, $979^{* *}$ &, $983^{* *}$ & 1 \\
\hline & 2004-2009 & $(0,082)$ & $(0,001)$ & $(0,000)$ & \\
\hline & \multirow[b]{2}{*}{$2010-2015$} & ,916* & ,916* &, $937^{* *}$ & 1 \\
\hline & & $(0,010)$ & $(0,010)$ & $(0,006)$ & \\
\hline & \multirow[b]{2}{*}{ 2016-2020 } & 0,395 & ,996** & ,996 & \multirow[t]{2}{*}{1} \\
\hline & & $(0,510)$ & $(0,000)$ & $(0,000)$ & \\
\hline \multicolumn{6}{|c|}{ **. Correlation is significant at the 0.01 level (2-tailed). } \\
\hline Te & I & evel (2-tailed). & & & \\
\hline
\end{tabular}

Source: Compiled by the authors.

Trend for 2016-2020. In this period, the destruction of the relationships observed earlier is noticeable. None of the indicators have any impact on the amount of money transferred. Conclusion: there is a shadow market in Kazakhstan, where cash is still actively used. There remains a strong relationship between the number of plastic cards and the volume of non-cash transactions $(, 996 * *)$.
Conclusion: earlier there was a theory that the higher the number of plastic cards among the population, the more money transfers will go through the national payment system. Now this connection has not been confirmed. Nevertheless, the expression «Non-cash payments are made only with a bank card» is still relevant. To carry out noncash transfers, a bank card is tied to mobile banking, various payment systems (PayPal, SumsungPay, AliPay, etc.) 
Further, Figure 2 shows the forecast compiled in Microsoft Excel. A polynomial trend line is used to build a forecast. This curve is characterized by variable increase and decrease.

For polynomials (polynomials), the degree is determined (by the number of maximum and minimum values). R2 is close in value to 1 (0.9402, 0.9543, 0.9783 and 0.9776), which indicates the minimum approximation error. To obtain such a value of approximation reliability, it was necessary to put the 4th degree, and for the volume of payments (Vol_P) the 5th degree. The resulting models made it possible to predict the number of payments (thousand transactions), the volume of payments (billion tenge), the number of cardholders (thousand), the total number of cards in circulation (thousand) for 2021-2023. No forecast was made for the total number of used payment cards.

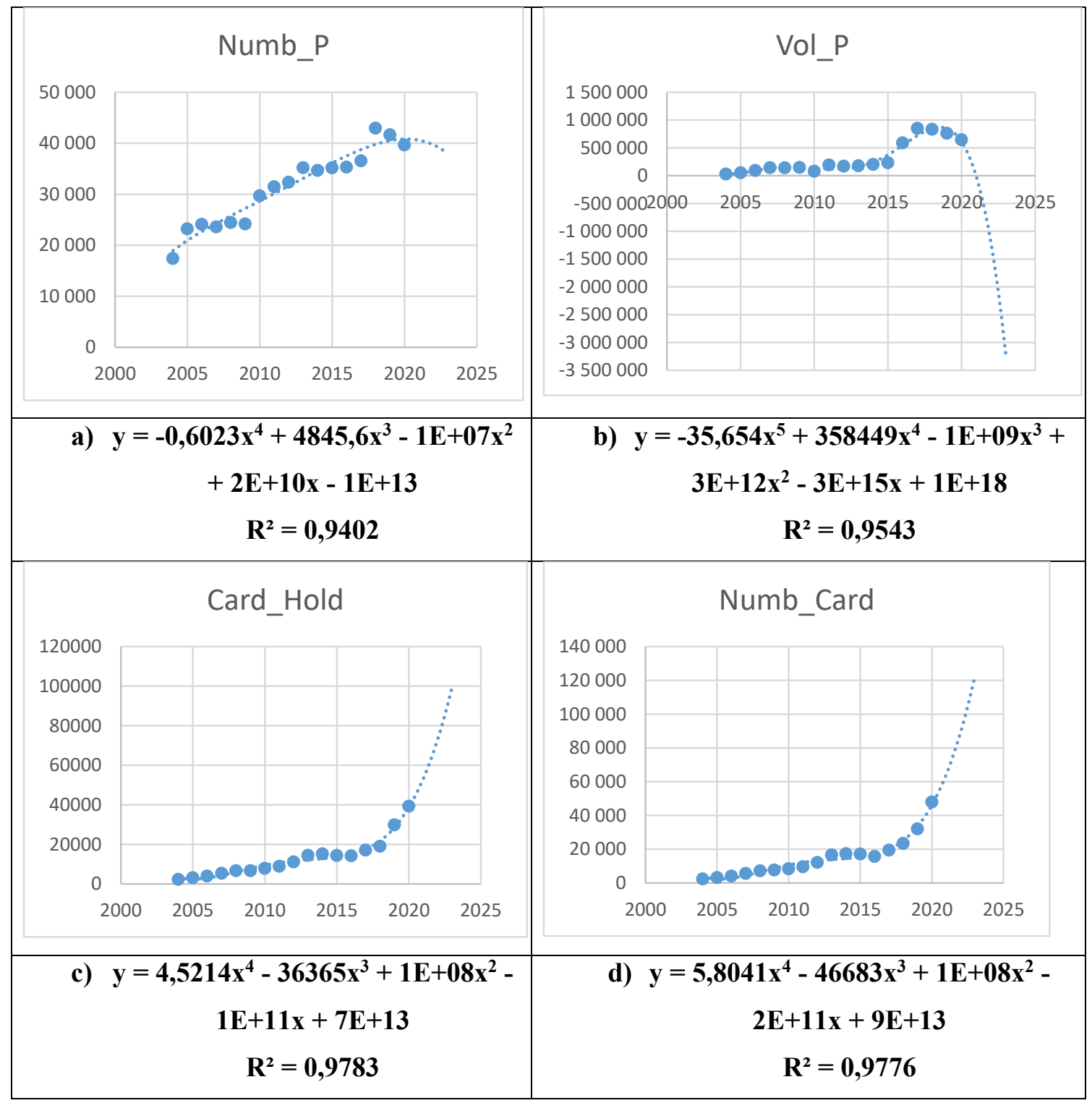

Figure 2 - The forecast of developing non-cash determinants in Kazakhstan 2021-2023:

a) forecast of number of payments, thous. Transactions;

b) forecast of volume of payments, billion tenge;

c) forecast of Number of card holders, thous.;

d) forecast of Total number of cards in circulation, thous.

Source: Compiled by the authors. 

drawn:

Thus, the following conclusions can be

H0 - null hypothesis - there is no relationship between payment cards and the volume of noncash settlements in Kazakhstan - is rejected.

H1 - an alternative hypothesis - there is a relationship between payment cards and the volume of cashless payments in Kazakhstan - has a logical confirmation.

\section{Conclusion}

The number of cardholders in Kazakhstan for 2020 has exceeded the population. This means that gradually cash will be reduced in circulation. The growth of cardholders is predicted and, as a consequence, the spread of the number of payment cards among the population. At the same time, the obtained forecast shows a decrease in the number and volume of payments in the coming years. To prevent this from happening, it is necessary to implement a state program to cover the population with the Internet by $100 \%$, it is necessary to increase digital and financial literacy among the population. The government should also support the development of the financial industry. It is then that the universal income declaration program will show a positive result.

The practical significance of this study is that the proposed methodology can help predict the dynamics of payment cards in any country in the world. Also, the forecast results can be used by other scientists in future studies.

Study limitation: This study did not consider gender. Also in the next studies, it is planned to cover regional data on payment cards and conduct a study in the gender context.

\section{References}

1. Idzik, M., \& Sobczak, K. (2018). Development of the payment cards market in Poland in comparison with other European Union countries. Wiadomości Statystyczne. The Polish Statistician 2018; 63(1): 77-95. https://doi.org/10.5604/01.3001.0014.0616

2. Goczek, L., \& Witkowski, B. (2015). Determinants of non-cash payments. National Bank of Poland Working Paper, (196). http://dx.doi.org/10.2139/ ssrn.2648824

3. Humphrey, D. B. (2004). Replacement of cash by cards in US consumer payments. Journal of Economics and Business, 56(3), 211-225. 5. https://doi. org/10.1016/j.jeconbus.2003.09.001

4. Arabadzhy, K., Zharnikova, V., \& Sobolieva-Tereshchenko, O. (2021). Transformation of cashless payments in the European payment card market. Management and Entrepreneurship: Trends of Development, 1(15), 8-23. https://doi. org/10.26661/2522-1566/2021-1/15-01.
5. Chen, R., Yamaka, W., \& Osathanunkul, R. (2019, October). Determinants of non-cash payments in Asian countries. In Journal of Physics: Conference Series 1324(1), 012103. IOP Publishing. https://doi. org/10.1088/1742-6596/1324/1/012103

6. Chang, S. J., Hsu, C. I., \& Lin, C. T. (2020). Using FAHP and CBR to evaluate the intention of adoption of internet banking service: The example of web ATM. Journal of Intelligent \& Fuzzy Systems, (Preprint), 1-11. https://doi.org/10.3233 / JIFS-191408

7. Salsabila, S.S. (2018). Eksistensi Kartu Kredit Dengan Adanya Electronic Money (E-Money) Sebagai Alat Pembayaran Yang Sah. Jurnal Privat Law, 6(1), 24-33. https://doi.org/10.20961/privat.v6i1.19222

8. Sokołowska, E. (2015). Innovations in the payment card market: The case of Poland. Electronic Commerce Research and Applications, 14(5), 292-304. https://doi.org/10.1016/j.elerap.2015.07.005

9. Polyakova, A. (2018). The Dynamics of the Russian Segment of E-Commerce and E-Payments. Monitoring of Russia's Economic Outlook. Moscow. IEP, (12), 14-18. http://dx.doi.org/10.2139/ ssrn. 3208635

10. Wiśniewski, J.W. (2018). Substitution of payments on the payment cards market in Poland. In X International Scientific Conference Analysis of International Relations. http://dx.doi. org/10.5604/01.3001.0014.0616

11. Snellman, J.S., Vesala, J.M., \& Humphrey, D.B. (2001). Substitution of noncash payment instruments for cash in Europe. Journal of Financial Services Research, 19(2), 131-145. http://dx.doi. org/10.1023/A:1011151219545

12. Aprigliano, V., Ardizzi, G., \& Monteforte, L. (2017). Using the payment system data to forecast the Italian GDP. Bank of Italy Temi di Discussione (Working Paper), 1098. http://dx.doi.org/10.2139/ssrn.2946969

13. Aprigliano, V., Ardizzi,G., \& Monteforte, L. (2019). Using payment system data to forecast economic activity. 60th issue (October 2019) of the International Journal of Central Banking.

14. National Bank of the Republic of Kazakhstan, [Electronic resource]. URL: https://nationalbank.kz/ru/ news/sistema-mezhbankovskogo-kliringa (access date: 05/10/2020).

15. The price of fixed-line broadband in 211 countries (converted thttps://www.cable.co.uk/ broadband/pricing/worldwide-comparison/, access data: 27.05 .2021 ) 


\section{Information about the authors}

* Anna A. Kredina - PhD, University of International Business, Kazakhstan, e-mail: anna.kredina@uib.kz.ORCID ID: ORCID 0000-0002-7682-2727

Olga V. Koshkina - Associate professor of University of International Business, Kazakhstan, e-mail: $\underline{\text { o.koshkina@ }}$ mail.ru. ORCID ID: ORCID 0000-0002-0847-3537

László Vasa - PhD, Széchenyi István University, Győr, Hungary, Full professor (Faculty of Economics), e-mail: laszlo.vasa@,ifat.hu. ORCID ID: ORCID 0000-0002-3805-0244

\section{Авторлар туралы мәліметтер}

* Кредина Анна Александровна - Халықаралық бизнес университеті, Қазақстан, e-mail: anna.kredina@uib. kz. ORCID ID: $\underline{\text { ORCID 0000-0002-7682-2727 }}$

Кошкина Ольга Валентиновна - доцент, Халықаралық бизнес университеті, Қазақстан, e-mail: o.koshkina@, mail.ru. ORCID ID: ORCID 0000-0002-0847-3537

Ласзло Васа - университет профессоры, Сечени Иштван Университеті, Дьер, Венгрия, e-mail: laszlo.vasa@ ifat.hu. ORCID ID: ORCID 0000-0002-3805-0244

\section{Сведения об авторах}

* Кредина Анна Александровна - докторант, Университет международного бизнеса, Казахстан, e-mail: anna. kredina@uib.kz.ORCID ID: ORCID 0000-0002-7682-2727

Кошкина Ольга Валентиновна - PhD, Университет международного бизнеса, Казахстан, e-mail: o.koshkina@, mail.ru. ORCID ID: ORCID 0000-0002-0847-3537

Ласзло Васа - профессор университета, Университет Сечени Иштвана, Венгрия, e-mail: laszlo.vasa@ifat.hu. ORCID ID: ORCID 0000-0002-3805-0244 